\title{
A Epidemiologia e as Práticas de Saúde Coletiva
}

\section{Claudio Maierovich Pessanha Henriques*}

A principal contribuição que temos a trazer origina-se da experiência que vimos acumulando nos últimos seis anos na implantação e na consolidação do Sistema Único de Saúde no nível local na cidade de Santos e, em particular, dos serviços relacionados mais diretamente à área de saúde pública. Adotando estas referências da chamada prática dos serviços, propomo-nos a problematizar alguns aspectos que julgamos relevantes.

Primeiramente cabe sublinhar os princípios que vêm regendo nosso modelo: a afirmação da competência municipal, a integração de ramos da saúde pública freqüentemente apartados dentro da organização institucional e, entre eles, a área assistencial.

Tem crescido a cada dia nossa convicção quanto ao acerto da municipalização, não apenas da execução, mas do planejamento e de parte da atividade normativa. Ela permite aumentar o alcance das ações na medida em que aproxima-nos da ocorrência dos problemas; nunca será demais lembrar que eles acontecem nos municípios, por serem os únicos entes federativos com identidade material, ao contrário dos estados e da Federação, que expressam exclusivamente a organização política formal e legal. Torna-se possível o efetivo controle social, tanto pelos mecanismos institucionalizados - como os conselhos de saúde - como pela visibilidade e facilidade de acesso inerentes ao poder local. Facilita-se a integração entre as vigilâncias, incluindo o controle de zoonoses, a saúde do trabalhador e as atividades programáticas, construindo uma malha inseparável também da assistência individual, com a tradução do tão alardeado enfoque de risco.

Tais avanços aliam-se à coordenação intersetorial, tão natural dentro de uma mesma prefeitura, à abertura de espaço para a eclosão de soluções mais

\footnotetext{
* Secretário de Higiene e Saúde de Santos
} 
criativas, à velocidade de circulação de informações, à eficiência muito maior na utilização de recursos e à agilidade na tomada de decisões. Esses trunfos, aparentemente simbólicos, podem representar a distância entre sucesso e fracasso de uma iniciativa. Aos que temem uma suposta fragilidade dos municípios para o enfrentamento de situações complexas, é bom lembrar que a complexidade dos problemas, via de regra, é proporcional à capacidade de resolvêlos, restando ao poder estadual a compensação das exceções e a coordenação macro-regional. Santos exerce hoje seu poder na área até além da interpretação hegemônica dos textos legais, como se pode exemplificar com nossas incursões na vigilância sanitária do porto.

Temos sido provocados pela discussão de modelos conceituais, quando às vezes opõem-se abstratamente o enfoque programático ou de risco e o de resposta à demanda. Talvez, remendando as tendências da moda, devêssemos parar de falar em vigilância à saúde e passar ao termo revigilância, pois aquelas duas concepções e sua interação transmutam-se em responsabilidades no campo da prática, e somos incessantemente cobrados nesse sentido. Mas se tem sido possível avançar no trabalho com os serviços básicos, pouco se pode dizer sobre as incursões da saúde coletiva junto à assistência especializada.

Especialmente quando nos defrontamos com a mudança no perfil de morbidade, a mal denominada "transição epidemiológica", é preciso enfrentar a discussão de conteúdos e de organização do trabalho nesse campo, ou melhor, no plural, no campos das especialidades médicas, pois seu agrupamento é uma simplificação artificial, fruto de nossa timidez de formulação e sedução. Nesse sentido, a reflexão e as bases para organização e avaliação destes serviços praticamente só têm tido contribuições mais efetivas no campo da chamada epidemiologia clínica, ainda que isso soe como provocação. Importante dizer, ainda, que filiamo-nos mais e mais a uma espécie de ecletismo de modelos, adotando, a depender da natureza dos desafios que nos colocamos, práticas que correspondem a diversas camadas de nossa arqueologia sanitária, do "campanhismo vertical" aos modelos integradores descentralizados, procurando garantir, seja qual for a vertente, ampla informação e participação.

Outro aspecto que é importante assinalar entre nossas tarefas prementes não cumpridas é elaboração de propostas de critérios epidemiológicos para 0 financiamento da saúde, conforme conseguimos inserir em nossa legislação. Assim, somente têm prevalecido para os repasses de recursos aos estados e municípios os parâmetros de produção de serviços e de população. Não se pretende aqui trazer uma solução de cartola, ou polemizar com aqueles que tanto se têm dedicado a tal missão, mas trazer-lhes alguma contribuição. Trata-se, em primeiro lugar, de lembrar a própria origem da disciplina - a epidemiologia - e conseguir apontar diferenças, tanto no campo dos determinantes, como dos efeitos sobre a saúde. Identificar, então, as possibilidades de intervenção setorial, pois freqüentemente embaraçamo-nos em meio a necessidades de investi- 
mentos cuja repercussão na saúde é imediata, com saneamento, estrutura fundiária, renda etc, mas cuja fonte de custeio é outra, e cabe-nos, setorialmente, chamar a atenção para tais responsabilidades. Feita tal delimitação, resta-nos distinguir situações, cujo impacto sobre os custos do sistema de saúde justificam prioridade, o que pode ser feito com base em nossos critérios mais tradicionais - freqüência, gravidade e vulnerabilidade - ou mais elaborados, que levem em conta o custo social e a premência de políticas sociais compensatórias. Para tanto, devemos, necessariamente angariar a colaboração de outras disciplinas, mais habilitadas ao trabalho com este tipo de indicador.

Outro mecanismo que não deve ser desprezado é o financiamento de projetos específicos, fugindo, no entanto, do casuísmo que costuma rondá-los, dando poder discricionário aos conselhos de saúde, assessorados pelas instâncias técnicas institucionais.

Mais do que trazer a discussão de critérios para este forum, é preciso recolocar o tema na ordem do dia e dar mais cores a sua urgência.

Por fim, um assunto preocupante colocado na ordem do dia é a reorganização proposta para a área de saúde coletiva no Estado de São Paulo, com a criação de uma coordenação específica, de natureza vertical. Embora reconhecendo o desmonte ocorrido nos dois últimos governos, com a utilização das estruturas regionais para a pequena política e a evasão de técnicos face à política salarial e a institucional, não se pode deixar de perguntar se para enfrentar tais adversidades circunstanciais não se abandona irreversivelmente a possibilidade de um modelo com implantação efetiva na rede assistencial, que pudesse se integrar horizontalmente aos serviços e respeitasse as instâncias de participação do SUS. Não parece o momento, ainda, de abandonar projetos que povoavam nossos sonhos, e muito menos de a área de saúde coletiva conformar-se como o isolamento que lhe foi imposto nesse passado recente. 